\title{
Test-retest stability of the Behavioural Assessment of the Dysexecutive Syndrome in a sample of psychiatric patients.
}

Citation for published version (APA):

Jelicic, M., Henquet, C. E. C., Derix, M. M. A., \& Jolles, J. (2001). Test-retest stability of the Behavioural Assessment of the Dysexecutive Syndrome in a sample of psychiatric patients. International Journal of Neuroscience, 110, 73-78. https://doi.org/10.3109/00207450108994222

Document status and date:

Published: 01/01/2001

DOI:

10.3109/00207450108994222

Document Version:

Publisher's PDF, also known as Version of record

Please check the document version of this publication:

- A submitted manuscript is the version of the article upon submission and before peer-review. There can be important differences between the submitted version and the official published version of record.

People interested in the research are advised to contact the author for the final version of the publication, or visit the DOI to the publisher's website.

- The final author version and the galley proof are versions of the publication after peer review.

- The final published version features the final layout of the paper including the volume, issue and page numbers.

Link to publication

\footnotetext{
General rights rights.

- You may freely distribute the URL identifying the publication in the public portal. please follow below link for the End User Agreement:

www.umlib.nl/taverne-license

Take down policy

If you believe that this document breaches copyright please contact us at:

repository@maastrichtuniversity.nl

providing details and we will investigate your claim.
}

Copyright and moral rights for the publications made accessible in the public portal are retained by the authors and/or other copyright owners and it is a condition of accessing publications that users recognise and abide by the legal requirements associated with these

- Users may download and print one copy of any publication from the public portal for the purpose of private study or research.

- You may not further distribute the material or use it for any profit-making activity or commercial gain

If the publication is distributed under the terms of Article $25 \mathrm{fa}$ of the Dutch Copyright Act, indicated by the "Taverne" license above, 
Intern. J. Neuroscience, 2001, Vol. 110, pp. 73-78

Reprints available directly from the publisher

Photocopying permitted by license only
(C) 2001 OPA (Overseas Publishers Association) N.V.

Published by license under the Gordon and Breach Scienœ Publishers imprint, a member of the Taylor \& Francis Group.

\title{
TEST-RETEST STABILITY \\ OF THE BEHAVIOURAL ASSESSMENT OF THE DYSEXECUTIVE SYNDROME IN A SAMPLE OF PSYCHIATRIC PATIENTS
}

\author{
MARKO JELICIC ${ }^{a, *}$, CÉCILE E. C. HENQUET ${ }^{a}$, \\ MAYKE M. A. DERIX ${ }^{b}$ and JELLE JOLLES ${ }^{a}$ \\ ${ }^{a}$ Academic Neuropsychology Department, Psychomedical Centre Vijverdal, \\ Maastricht Brain and Behaviour Institute and European Graduate \\ School of Neuroscience (EURON), University of Maastricht, \\ The Netherlands; 'bepartment of Clinical Psychology, \\ Twenteborg Hospital, Almelo, The Netherlands
}

(Received 12 March 2001)

The Behavioural Assessment of the Dysexecutive Syndrome (BADS) is a relatively new test battery designed to measure disorders of executive functions. We studied the temporal stability of the BADS in a sample of 22 adult psychiatric patients. All patients were administered the BADS twice with an interval of 3 weeks. Test-retest correlations for the BADS tests ranged from .22 to .85 . On the repeat administration, patients obtained higher scores on one test as well as on the total BADS. Our results suggest that the BADS should not be administered on two occasions a few weeks apart.

Keywords: Executive functions; Neuropsychological testing; Psychiatric patients

In clinical neuropsychology, it is common practice to assess patients' cognitive functions on different occasions (Lezak, 1995). Traumatic brain injury patients, for instance, are tested repeatedly to determine

*Address for correspondence: Academic Neuropsychology Department, Psychomedical Centre Vijverdal, P. O. Box 88,6200 AB Maastricht, The Netherlands. e-mail: m.jelicic@np.unimaas.nl 
recovery of brain functions. Elderly with suspected dementia are given repeat assessments in order to establish further cognitive decline. Psychiatric patients are administered neuropsychological tests on more than one occasion, to examine the effects of psychotropic medications. To be used repeatedly, neuropsychological tests should have high testretest stability. It is difficult to interpret changes in performance on tests with questionable temporal stability: A higher score on the repeat administration of a test may reflect genuine cognitive improvement, a mere practice effect, or a combination of both improvement and practice.

Neuropsychological tests designed to measure executive functions (planning, monitoring, and organization of behavior) often have low test-retest reliability. In a study by Paolo et al. (1996) healthy older adults were administered the Wisconsin Card Sorting Test (WCST) twice. The authors found that all of the WCST scales had low stability coefficients (but see Ingram et al., 1999, for slightly different results). De Zubicaray et al. (1998) studied the temporal stability of the Modified Card Sorting Test (MCST) in a healthy older sample, and reported a low MCST test-retest reliability. Why do card sorting tests have low temporal stability? Burgess (1997) argued that in most executive tests subjects are confronted with novel problems which they will have to solve. When administered a second time, the novelty is gone and the test no longer measures problem-solving abilities. The Behavioural Assessment of the Dysexecutive Syndrome (BADS) is a relative new instrument developed to assess disorders of executive functions (Wilson et al., 1997; 1998). In contrast with traditional executive tests, the BADS is considered to be 'ecological valid,' i.e., the instrument aims to measure deficits in everyday life. Wilson et al. (1998) studied the temporal stability of the BADS. A group consisting of 29 normal subjects was administered the BADS twice, with an interval of 6-12 months. Although the test-retest correlations were moderate, no significant improvement in test performance was found on the repeat adminstration. The present study was initiated to investigate the temporal stability of the BADS in a clinical population. Since executive dysfunction is a feature of many psychiatric disorders (Grant and Adams, 1996), we decided to examine the instrument's test-retest reliability in a group of psychiatric patients. 


\section{METHODS}

\section{Subjects}

Our sample consisted of 22 adult psychiatric patients with different diagnoses (e.g., schizophrenia, affective disorders, obsessive compulsive disorder etc.). Mean age of the subjects was $40 \mathrm{yrs}$ ( $S D$ 8.8), mean IQ was 101 ( $S D$ 16.7). All patients were in remission.

\section{Procedure}

All patients were administered the Dutch version of the BADS (Krabbendam and Kalff, 1998) twice with an interval of 3 weeks. The BADS consists of six tests (Wilson et al., 1996). For each of the tests a summary profile score is obtained (with a minimum of 0 and a maximum of 4) and these are added up to obtain a total profile score (with a maximum of 24). The Rule Shift Card Test uses playing cards and evaluates the ability of subjects to respond correctly to a rule and to rule shifting. In the Action Program Test, subjects are asked to solve a practical problem, i.e., to remove a cork from a small tube using a few props. The Key Search Test is used to assess search strategies. Subjects are presented with a piece of paper containing an imaginary square and requested to draw a path to find a lost key. In the Temporal Judgement Test subjects are asked to make time judgments, for example "How long do most dogs live for?" The Zoo Map Test examines route planning. Subjects are given a map of a zoo and instructed to visit locations of the zoo while obeying certain rules. In the Modified Six Elements Test the ability to plan, organize and monitor behavior, is measured. Subjects are given six tasks which they have to do in 10 minutes. It is impossible to complete all tasks within the time limit.

\section{Data Analysis}

We first calculated Spearman test-retest correlations of the six BADS tests and the total BADS score. To find out if the BADS scores at the initial test session differed from the repeat administration, Wilcoxon matched-pairs tests were performed. We opted for nonparametric 
statistical methods because the BADS scores were not normally distributed.

\section{RESULTS}

The scores on the first and second administration of the BADS are presented in Table $\mathrm{I}$. The Action Program Test had a test-retest correlation coefficient of .22. For the Rule Shift Card Test, the Temporal Judgement Test, The Zoo Map Test, and the Modified Six Elements Test, correlations ranged from .48 to .60 . Both the Key Search Test and the total BADS had a test-retest correlation over 80 . Compared to the initial test session, patients had higher scores on the repeat administration of both the Action Program Test and the total $\operatorname{BADS}(p<.01)$.

\section{DISCUSSION}

In line with research using card sorting tasks ( $c f$. de Zubicaray et al., 1998), most of the test-retest correlations of the BADS tests failed to reach the minimum of .80 required for a clinical psychometric instrument (Anastasi and Urbina, 1997). The test-retest correlation of the total BADS was higher than .80 , suggesting that the overall score may be used in repeat measurements. However, the second test session yielded significantly higher total BADS scores than the initial test administration, indicative of a practice effect. In most of the BADS tests subjects are asked to solve a new problem. It seems likely

TABLE I Test-retest stability for the BADS tests

\begin{tabular}{lccc}
\hline Test & $\begin{array}{c}\text { 1st administration } \\
\text { mean }(S D)\end{array}$ & $\begin{array}{c}\text { 2nd administration } \\
\text { mean } S D\end{array}$ & Correlation \\
\hline Rule Shift Card & $2.86(1.42)$ & $3.00(1.11)$ & .60 \\
Action Program* & $3.27(1.03)$ & $4.00(0)$ & .22 \\
Key Search & $2.27(1.55)$ & $2.45(1.30)$ & .84 \\
Temporal Judgement & $1.77(.81)$ & $1.91(.81)$ & .50 \\
Zoo Map & $1.95(1.43)$ & $2.27(1.39)$ & .48 \\
Modified Six Elements & $3.00(1.31)$ & $3.27(.94)$ & .48 \\
Overall BADS* & $15.00(5.35)$ & $16.82(3.90)$ & .85 \\
\hline
\end{tabular}

* Difference between 1 st and 2 nd administration: $p<.01$. 
that patients obtained higher scores on the repeat administration of the BADS because the tests had lost their novelty ( $c f$. Burgess, 1997). This especially would have been the case for the Action Program Test.

Wilson et al. (1998) studied the temporal stability of the BADS in normal subjects. They found moderate test-retest correlations, but no significant differences in performance between the first and second test administration. In contrast, our subjects demonstrated improved performance on the Action Program Test and the overall BADS. How to explain these discrepant findings? Our sample consisted of psychiatric patients, who as a group exhibited poor executive functioning. Krabbendam et al. (1999) administered the BADS to schizophrenic patients and normal controls. The mean total BADS score was 19.1 for the control subjects and 16.1 for the patients. At the first test session, the mean overall BADS score of our study group was 1.1 point below that of the schizophrenic group of Krabbendam and her colleagues. Thus, our subjects had substantial "room for improvement" on the second administration of the BADS. Possibly, Wilson et al. (1998) did not find practice effects in their study, because normal subjects have little to gain on a repeat administration of the BADS.

Our findings suggest that, in clinical psychiatric practice, the BADS should not be administered on two occasions a few weeks apart. Further research is necessary to determine the temporal stability of the BADS in psychiatric patients using longer time intervals, and in other patient populations.

\section{References}

Anastasi, A. \& Urbina, S. (1997) Psychological testing, 7th edn., Englewood Cliffs, NJ: Prentice Hall.

Burgess, P. W. (1997) Theory and methodology in executive function research. In: Rabbitt, P. (Ed.), Methodology of frontal and executive function (pp. 81-116). Hove: Psychology Press.

de Zubicaray, G. I., Smith, G. A., Chalk, J. B. \& Semple, J. (1998) The Modified Card Sorting Test: Test-retest stability and relationships with demographic variables in a healthy older adult sample. British Journal of Clinical Psychology, 37, 457-466.

Grant, I. \& Adams, K. M. (1996) Neuropsychological assessment of neuropsychiatric disorders, 2nd edn., Oxford: Oxford University Press.

Ingram, F., Greve, K. W., Fishel Ingram, P. T. \& Soukop, V. M. (1999) Temporal stability of the Wisconsin Card Sorting Test in an untreated patient sample. British Journal of Clinical Psychology, 38, 209-211. 
Krabbendam, L. \& Kalf, A. C. (1998) The Behavioural Assessment of the Dysexecutive Syndrome - Dutch version. Lisse: Swets \& Zeitlinger.

Krabbendam, L., de Vugt, M. E., Derix, M. M. A. \& Jolles, J. (1999) The Behavioural Assessment of the Dysexecutive Syndrome as a tool to assess executive functions in schizophrenia. The Clinical Neuropsychologist, 13, 370-375.

Lezak, M. D. (1995) Neuropsychological assessment, 3rd edn., Oxford: Oxford University Press.

Paolo, A. M., Axelrod, B. N. \& Tröster, A. I. (1996) Test-retest stability of the Wisconsin Card Sorting Test. Assessment, 3, 137-143.

Wilson, B. A., Alderman, N., Burgess, P., Emslie, H. \& Evans, J. (1996) Behavioural Assessment of the Dysexecutive Syndrome. Bury St Edmunds: Thames Valley Test Company.

Wilson, B. A., Evans, J. J., Alderman, N., Burgess, P. W. \& Emslie, H. (1997) Behavioural Assessment of the Dysexecutive Syndrome. In: Rabbitt, P. (Ed.), Methodology of frontal and executive function (pp. 239-250). Hove: Psychology Press.

Wilson, B. A., Evans, J. J., Emslie, H., Alderman, N. \& Burgess, P. (1998) The development of an ecologically valid test for assessing patients with a dysexecutive syndrome. Neuropsychological Rehabilitation, 8, 213-228. 